\title{
Haplosporidium littoralis sp. nov.: a crustacean pathogen within the Haplosporida (Cercozoa, Ascetosporea)
}

\author{
G. D. Stentiford ${ }^{1, *}$, K. S. Bateman ${ }^{1}$, N. A. Stokes ${ }^{2}$, R. B. Carnegie ${ }^{2}$ \\ ${ }^{1}$ European Union Reference Laboratory for Crustacean Diseases, Centre for Environment, \\ Fisheries and Aquaculture Science (Cefas), Weymouth laboratory, Weymouth, Dorset DT4 8UB, UK \\ ${ }^{2}$ Virginia Institute of Marine Science, College of William \& Mary, PO Box 1346, Gloucester Point, Virginia 23062, USA
}

\begin{abstract}
Previously, we described the pathology and ultrastructure of an apparently asporous haplosporidian-like parasite infecting the common shore crab Carcinus maenas from the European shoreline. In the current study, extraction of genomic DNA from the haemolymph, gill or hepatopancreas of infected C. maenas was carried out and the small subunit ribosomal DNA (SSU rDNA) of the pathogen was amplified by PCR before cloning and sequencing. All 4 crabs yielded an identical 1736 bp parasite sequence. BLAST analysis against the NCBI GenBank database identified the sequence as most similar to the protistan pathogen group comprising the order Haplosporida within the class Ascetosporea of the phylum Cercozoa Cavalier-Smith, 1998. Parsimony analysis placed the crab pathogen within the genus Haplosporidium, sister to the molluscan parasites $H$. montforti, $H$. pickfordi and $H$. lusitanicum. The parasite infecting $C$. maenas is hereby named as Haplosporidium littoralis sp. nov. The presence of a haplosporidian parasite infecting decapod crustaceans from the European shoreline with close phylogenetic affinity to previously described haplosporidians infecting molluscs is intriguing. The study provides important phylogenetic data for this relatively understudied, but commercially significant, pathogen group.
\end{abstract}

KEY WORDS: Haplosporidia $\cdot$ Crab $\cdot$ Carcinus maenas $\cdot$ Disease $\cdot$ Littoral zone Resale or republication not permitted without written consent of the publisher

\section{INTRODUCTION}

The class Ascetosporea within the phylum Cercozoa Cavalier-Smith, 1998 comprises 2 important, but understudied invertebrate pathogen orders, the Haplosporida (including the genera Haplosporidium, Minchinia, Urosporidium and Bonamia), and the Paramyxida (containing Marteilia, Paramarteilia and Paramyxa). The Haplosporida infect invertebrate hosts from marine and freshwater habitats. Certain species within the representative genera are considered important pathogens of commercially harvested molluscs, with some (e.g. Bonamia spp.) even listed in international legislation concerning the movement of live animals for aquaculture (OIE 2012).
Although Perkins (2000, p. 1332) described the Haplosporida as 'parasitic protists that form ovoid, walled spores with an orifice covered externally by a hinged lid or internally by a flap of wall material', further assessment of morphological variants plus the addition of molecular phylogenetic analyses have supported inclusion of the apparently non-spore forming genus Bonamia within the Haplosporida (Carnegie et al. 2000, Reece et al. 2004, Hine et al. 2009), a placement that was confirmed with the recent description of the conventionally spore-forming species B. perspora (Carnegie et al. 2006). By identifying Bonamia too as a spore-forming genus, even though $B$. ostreae and $B$. exitiosa have never been observed to form spores, the discovery of $B$. perspora 
underscored the fact that pathological assessment of limited numbers of hosts may only provide a partial view on actual life stages present within a given host species. In addition to the formation of spores, the presence of haplosporosomes appears to be a common feature of members of Haplosporida, though once again, these may only appear in the spore stages of certain species. They may therefore remain enigmatic in those members for which these sexual stages have not been described (Hine et al. 2009). Within the group, the genus Haplosporidium is the largest, containing 23 named species and 3 tentative placements (Hine et al. 2009). However, molecular phylogenetics reveals this genus to be paraphyletic (Reece et al. 2004), likely representing an artificial grouping of numerous taxa.

To date, very few haplosporidians have been described as pathogenic agents in crustacean hosts. Haplosporidium cadomensis (Marchand \& Sprague 1979), H. louisiana (Sprague 1963), Claustrosporidium gammari (Larsson 1987) and unclassified forms apparently lacking spores (Newman et al. 1976, Dyková et al. 1988) have been reported. It is likely that $H$. cadomensis, H. louisiana and Haplosporidium sp. (Rosenfield et al. 1969) from crabs may be conspecific (Perkins \& van Banning 1981). Several apparently asporous haplosporidian-like pathogens have also been described infecting crustacean hosts, including blue crabs Callinectes sapidus from the USA (Newman et al. 1976); spot prawns (Pandalus spp.) from the coasts of Alaska and western Canada (Meyers et al. 1994, Bower \& Meyer 2002, Reece et al. 2004, Hine et al. 2009); European shore crabs Carcinus maenas from British waters (Stentiford et al. 2004); and farmed Litopenaeus vannamei from Central America and Asia (Dyková et al. 1988, Nunan et al. 2007, Utari et al. 2012). Spore-forming haplosporidians of crustaceans have been described infecting the decapod Rhithropanopeus harrisii tridentatus (Marchand \& Sprague 1979) and recently from freshwater amphipods of the genus Diporeia (Messick 2009). In the recent review by Hine et al. (2009), comparison of morphological and molecular features of pathogens reported in the literature as haplosporidians tentatively placed the apparently asporous group in a basal position within the taxon. It should be noted, however, that the asporous characteristic may simply reflect an as-yet undiscovered spore stage in these hosts, or alternatively, their role as an intermediate host to a definitive host in which the spore is formed (Stentiford et al. 2004).

This paper provides phylogenetic data for the presumptive haplosporidian pathogen infecting Euro- pean Carcinus maenas collected from the shoreline of the English Channel, UK (Stentiford et al. 2004). It places the pathogen within the order Haplosporida and more specifically as a new species within the genus Haplosporidium. The taxonomic position of the parasite is discussed in comparison to other haplosporidians infecting molluscan and crustacean hosts.

\section{MATERIALS AND METHODS}

\section{Collection and histology}

European shore crabs Carcinus maenas were collected from the shoreline at Newton's Cove, Weymouth, UK $\left(50^{\circ} 34^{\prime} \mathrm{N}, 2^{\circ} 22^{\prime} \mathrm{W}\right)$ between 2007 and 2011 as part of ongoing surveys by our laboratory. All crabs sampled appeared externally normal. Crabs were anaesthetised by chilling on ice prior to dissection. For histopathology, the hepatopancreas, gills, heart, midgut, gonad and skeletal muscles from the abdomen, cephalothorax and claw were dissected from each specimen. Excised samples were placed immediately into Davidson's seawater fixative. Fixation was allowed to proceed for $24 \mathrm{~h}$ before samples were transferred to $70 \%$ industrial methylated ethanol for storage prior to processing. Fixed samples were processed to wax in a vacuum infiltration processor using standard protocols. Sections were cut at a thickness of 3 to $5 \mu \mathrm{m}$ on a rotary microtome and were mounted onto glass slides before staining with haematoxylin and eosin (HE). Stained sections were analysed by light microscopy (Nikon Eclipse E800), and digital images were taken using the LuciaTM Screen Measurement System (Nikon). For electron microscopy, $2 \mathrm{~mm}^{3}$ blocks of hepatopancreas were fixed in a solution containing $2.5 \%$ glutaraldehyde in $0.1 \mathrm{M}$ sodium cacodylate buffer ( $\mathrm{pH} 7.4$ ), for $2 \mathrm{~h}$ at room temperature prior to rinsing in $0.1 \mathrm{M}$ sodium cacodylate buffer with $1.75 \%$ sodium chloride ( $\mathrm{pH} 7.4$ ) and post-fixation in $1 \%$ osmium tetroxide in $0.1 \mathrm{M}$ sodium cacodylate buffer for $1 \mathrm{~h}$ at $4^{\circ} \mathrm{C}$. Specimens were washed in 3 changes of $0.1 \mathrm{M}$ sodium cacodylate buffer and dehydrated through a graded acetone series. Specimens were embedded in Agar 100 epoxy resin (Agar Scientific, Agar 100 pre-mix kit medium) and polymerised overnight at $60^{\circ} \mathrm{C}$ in an oven. Semi-thin (1-2 $\mu \mathrm{m})$ sections were stained with Toluidine Blue for viewing with a light microscope to identify suitable target areas. Ultrathin sections (70-90 nm) of target areas were mounted on uncoated copper grids and stained with $2 \%$ aqueous 
uranyl acetate and Reynolds' lead citrate (Reynolds 1963). Grids were examined using a JEOL JEM 1210 transmission electron microscope and digital images captured using a Gatan Erlangshen ES500W camera and Gatan Digital Micrograph ${ }^{\mathrm{TM}}$ software. Pathological and ultrastructural data were used to identify appropriate samples for molecular phylogenetic analyses and to provide a formal taxonomic classification of the presumptive haplosporidian pathogen in C. maenas.

\section{DNA extraction and polymerase chain reaction $(\mathrm{PCR})$}

Samples of haemolymph and of gill or hepatopancreas corresponding to those regions sampled for histology and electron microscopy were dissected and placed into absolute ethanol. Total genomic DNA was extracted from tissues of 4 crabs using the QIAamp DNA Mini kit (Qiagen) according to manufacturer's protocol, and DNA was quantified using a NanoDrop 2000 spectrophotometer (Thermo Scientific).

Initial PCR attempts to amplify the small subunit ribosomal DNA (SSU rDNA) of the putative haplosporidian using haplosporidian-targeted PCR assays (e.g. Renault et al. 2000) were unsuccessful. PCR was then attempted with primers 18S-EUK581f (5'-GTG CCA GCA GCC GCG-3') and 18S-EUK1134r (5'-TTT AAG TTT CAG CCT TGC G-3'), which were designed to selectively amplify approximately $550 \mathrm{bp}$ from the middle section of SSU rDNA of nonmetazoans (Carnegie et al. 2003, Bower et al. 2004). Reactions contained buffer (10 mM Tris- $\mathrm{HCl} \mathrm{pH}$ 8.3, $50 \mathrm{mM} \mathrm{KCl}, 2.0 \mathrm{mM} \mathrm{MgCl}$, $0.001 \%$ gelatin; Applied Biosystems), each deoxyribonucleotide at $0.2 \mathrm{mM}$, $0.4 \mu \mathrm{g}$ bovine serum albumin, each primer at $12.5 \mathrm{pmol}$, 0.6 U AmpliTaq DNA polymerase (Applied Biosystems), and 200 to 250 ng DNA. Cycling parameters were as published (Carnegie et al. 2003), except that the initial denaturation was decreased to $4 \mathrm{~min}$. DNA from Carcinus maenas haemolymph samples yielded a single 554 bp product, while DNA from hepatopancreas and gill samples yielded the 554 bp amplicon along with 2 other products.

\section{DNA sequencing and phylogenetics}

Sequencing results from the non-metazoan PCR product permitted design of specific primers within this region that were paired with general eukaryotic primers 16S-A and 16S-B (Medlin et al. 1988) to amplify the 5' and 3' ends of the crab haplosporidian SSU rDNA. These new PCR assays used primers 16SA (5'-AAC CTG GTT GAT CCT GCC AGT-3') + CHr2 (5'-ACT GCG AAA AGC GCT AGC ACG-3') and CHf3 (5'-CAA GAA CTA AAG CCC GGG GAT C-3') + 16S-B (5'-GAT CCT TCC GCA GGT TCA CCT AC-3'), yielding single products of 628 and $773 \mathrm{bp}$, respectively. PCR reaction mixtures were the same as described above except that $\mathrm{MgCl}_{2}$ was $1.5 \mathrm{mM}$ and cycling parameters involved initial denaturation at $94^{\circ} \mathrm{C}$ for $4 \mathrm{~min}$, cycling 35 times at $94^{\circ} \mathrm{C}$ for $30 \mathrm{~s}, 55^{\circ} \mathrm{C}$ for $30 \mathrm{~s}, 72^{\circ} \mathrm{C}$ for $2 \mathrm{~min}$, and final extension at $72^{\circ} \mathrm{C}$ for $5 \mathrm{~min}$.

When PCR generated only a single product, triplicate reactions were pooled and purified with the QIAquick PCR Purification kit (Qiagen). When PCR generated multiple products, 3 to 5 reactions were pooled, products were separated by agarose gel electrophoresis prior to the desired band being excised from the gel using a sterile razor blade, and purified with the QIAquick Gel Extraction kit (Qiagen). PCR products were ligated into plasmid vector pCR4TOPO and transformed into chemically competent E. coli using the TOPO TA Cloning kit (Invitrogen) according to the manufacturer's protocol. Clones were sequenced using M13 forward and reverse primers (New England Biolabs) and the BigDye Terminator v3.1 Cycle Sequencing kit (Applied Biosystems). Sequencing reactions were electrophoresed on $80 \mathrm{~cm}$ 16-capillary ABI 3130 Genetic Analyzer using Sequencing Analysis 5.2 software for base-calling (Applied Biosystems). Sequencing of both strands was done with 8 clones per SSU rDNA fragment (5' end, middle, 3 ' end) per sample.

Sequences were aligned using CodonCode Aligner, version 3.7.1.1 (LI-COR). The resultant SSU rDNA sequence obtained from infected Carcinus maenas was subjected to BLAST search (Altschul et al. 1997) using the GenBank sequence database. For phylogenetic analysis, the SSU rDNA sequence of the crab parasite was aligned in ClustalW with haplosporidian SSU rDNA sequences from the Haplosporidium sp. ex Ostrea edulis (GenBank accession AY781176), H. costale (U20858), H. edule (DQ458793), H. louisiana (U47851), H. lusitanicum (AY449713), H. montforti (DQ219484), H. nelsoni (U19538), H. pickfordi (AY452724), H. raabei (HQ176468), H. tuxtlensis (JN368430), Minchinia chitonis (AY449711), M. mercenariae (FJ518816), $M$. occulta (EF165631), M. tapetis (AY449710), M. teredinis (U20319), Bonamia exitiosa from the USA (AY542903) and from New Zealand (AF337563), $B$. ostreae (AF262995), B. roughleyi (AF508801), B. per- 
spora (DQ356000), Urosporidium sp. from Stictodora lari (AY449714), U. crescens (U47852), and haplosporidians from Cyrenoida floridana (AY449712), Haliotis iris (AF492442), Pandalus platyceros (AY449716), Litopenaeus vannamei in Belize (DQ653412) and Indonesia (HQ285783), Ruditapes decussatus (AY435093) and Syllis nipponica (DQ444238). Parsimony bootstrap analysis was performed in PAUP version 4.0b10 (Swofford 2002) with characters weighted equally and gaps treated as missing data, and with haplosporidians from Haliotis iris and Pandalus platyceros used as the outgroup species, based on the phylogenetic results obtained by Reece et al. (2004). Starting trees were obtained by stepwise addition, with the addition sequence simple and one tree held during each step, followed by branch swapping by tree-bisection-reconnection.

\section{In situ hybridisation}

Fluorescent in situ hybridisation (FISH) was performed to definitively demonstrate that the SSU rDNA sequence described above came from the plasmodia observed by microscopic examination. An oligonucleotide probe, CH1339-AF (5'-CGG TGT CGA GCA CTA CAA AAG-3'), was designed to specifically anneal to the crab parasite and then commercially synthesized and 5'-end labelled with Alexa fluor 488 (Life Technologies). FISH was conducted as described by Carnegie et al. (2006). Tissue sections of infected Carcinus maenas were hybridised with probes $\left(10 \mathrm{ng} \mathrm{hl}^{-1}\right)$ CH1339-AF, Perksp700-AF (Elston et al. 2004; labelled with Alexa Fluor 488 instead of digoxigenin) or no probe, the latter 2 treatments of which were included as negative controls. Probe specificity was tested by performing FISH with CH1339-AF on sections of crab, and of oyster Crassostrea virginica infected with Haplosporidium costale. All FISH slides were examined using an Olympus Provis epifluorescence microscope with a red-green dual bypass filter.

\section{RESULTS}

\section{Field observations, histopathology and ultrastructure}

Haplosporidian infection, observed via presence of opaque haemolymph upon dissection, and associated distinctive histopathology occurred in 26 of 338 Carcinus maenas (apparent prevalence $7.6 \%$ ) sampled over the study period. Haemocytes, connective tissue cells, reserve inclusion cells, gill epithelial cells and occasionally muscle fibres contained large, eosinophilic parasitic plasmodia. In late stage infections, liberated uninucleate stages were observed within the haemal sinuses of all major organs and tissues (Fig. 1a,b).

Ultrastructural features of the crab haplosporidian were largely consistent with the previous observations by our laboratory. In brief, 3 distinct life stages: a free uninucleate form, a multinucleate plasmodium, and a membrane-bound multicellular plasmodial stage (containing uninucleate parasites with similar morphology to the free uninucleate stage) were frequently encountered in haemal spaces and associated with the aforementioned host cell types. Uninucleate forms contained an electron lucent cytoplasm, dense vesicles (DVs), haplosporosome-like bodies (HLBs) and ovoid lucent vesicles (OLVs). Multinucleate plasmodial stages ranged from binucleate forms to large cells containing over 20 nuclei in section. These nuclei often appeared closely opposed but not connected. As seen in uninucleate forms, DVs, HLBs and OLVs were usually observed within the plasmodial cytoplasm. Formation of membranes around discrete nuclei (and enclosing HLBs, DVs and OLVs) was once again presumed to preempt the re-formation of uninucleate stages (thereby creating the multicellular plasmodial stage. Whilst a detailed description of the ultrastructure of the pathogen is available in previous work from our laboratory (Stentiford et al. 2004), a representative image of uninucleate and plasmodial life stages is given in Fig. 1c.

\section{Molecular taxonomy}

PCR amplification and sequencing of SSU rDNA from infected Carcinus maenas yielded one $1736 \mathrm{bp}$ consensus sequence (GenBank accession JX185413). BLAST analysis suggested that this sequence was haplosporidian, revealing a $79 \%$ maximum identity to both Haplosporidium tuxtlensis (JN368430) and Haplosporidium sp. ex Ostrea edulis (AY781176). Parsimony bootstrap analysis of a 2167-character SSU rDNA sequence dataset, 838 characters of which were parsimony-informative, placed this novel sequence on a clade comprising the gastropod parasites $H$. montforti, H. lusitanicum, H. pickfordi and $H$. tuxtlensis, and the haplosporidian from the polychaete Syllis nipponica (Fig. 2). While the analysis suggested a sister relationship of our sequence to the 

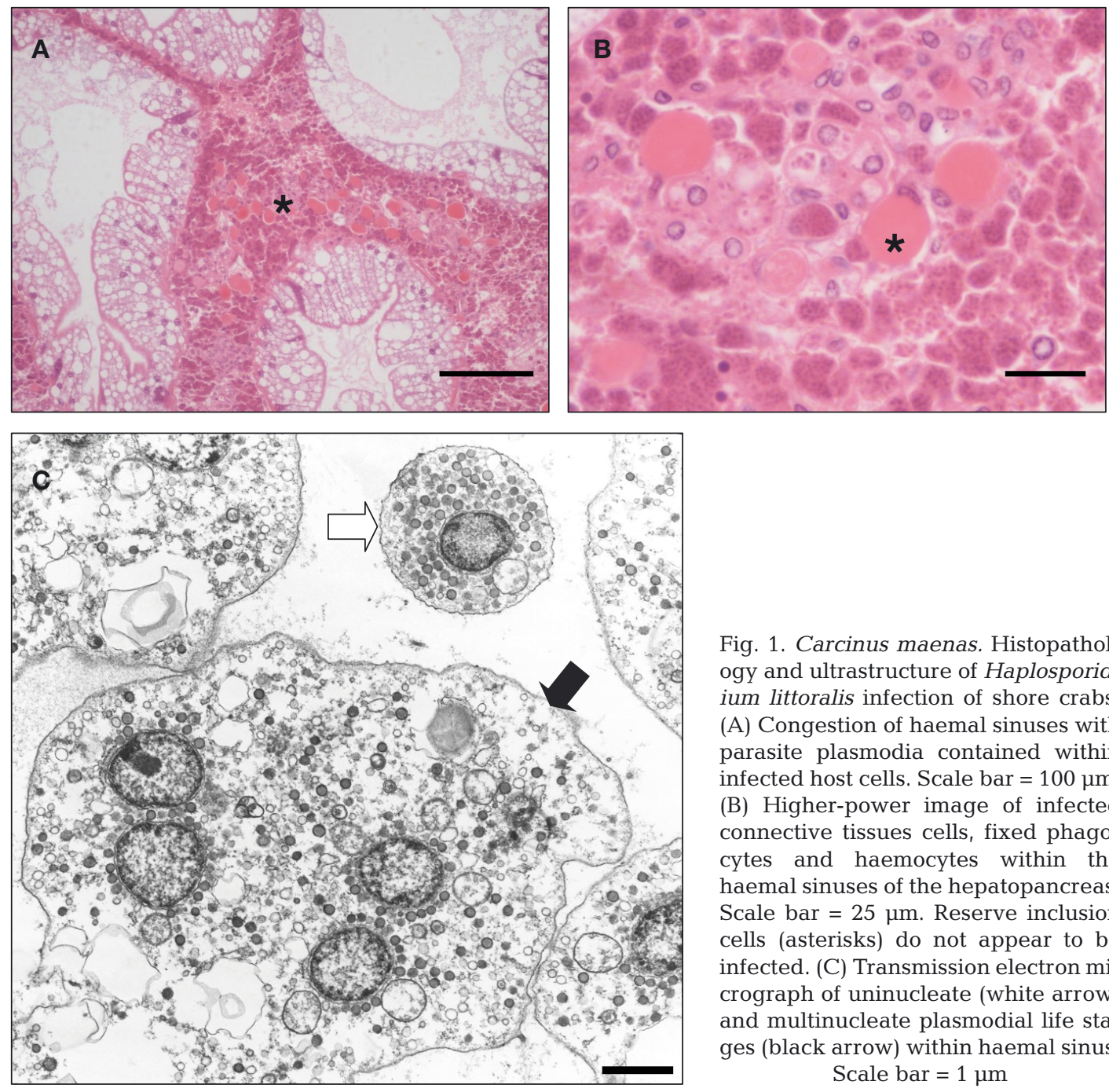

Fig. 1. Carcinus maenas. Histopathology and ultrastructure of Haplosporidium littoralis infection of shore crabs. (A) Congestion of haemal sinuses with parasite plasmodia contained within infected host cells. Scale bar $=100 \mu \mathrm{m}$. (B) Higher-power image of infected connective tissues cells, fixed phagocytes and haemocytes within the haemal sinuses of the hepatopancreas. Scale bar $=25 \mu \mathrm{m}$. Reserve inclusion cells (asterisks) do not appear to be infected. (C) Transmission electron micrograph of uninucleate (white arrow) and multinucleate plasmodial life stages (black arrow) within haemal sinus. Scale bar $=1 \mu \mathrm{m}$

S. nipponica haplosporidian, this relationship was not strongly supported (bootstrap value: 55). This clade was sister to another comprising $H$. costale, $H$. edule, $H$. raabei and Haplosporidium sp. ex $O$. edulis. SSU rDNA phylogenetics thus indicated placement of the haplosporidian sequence from $C$. maenas in the genus Haplosporidium.

\section{In situ hybridisation}

The probe CH1339, which targets a variable region near the 3' end of the Carcinus maenas parasite's SSU rDNA, hybridised only with the haplosporidianlike plasmodia identified by microscopic examination of histologically stained C. maenas tissue sections (Figs. $3 \& 4$ ). The probe did not hybridise with uninfected crab tissues nor with another haplosporid- ian from molluscs, and fluorescence indicating probe binding to plasmodia was obtained only with probe CH1339. In situ hybridisation therefore provided definitive evidence linking the novel SSU rDNA sequence to the $C$. maenas parasite observed histologically. The C. maenas parasite is a new Haplosporidium sp., the description of which we provide herein.

\section{TAXONOMIC SUMMARY}

Phylum: Cercozoa Cavalier-Smith, 1998

Sub Phylum: Endomyxa Cavalier-Smith, 2002

Class: Ascetosporea Cavalier-Smith, 2002

Order: Haplosporida Caullery \& Mesnil, 1899

Family: Haplosporidiidae Sprague, 1979

Genus: Haplosporidium Caullery \& Mesnil, 1899 


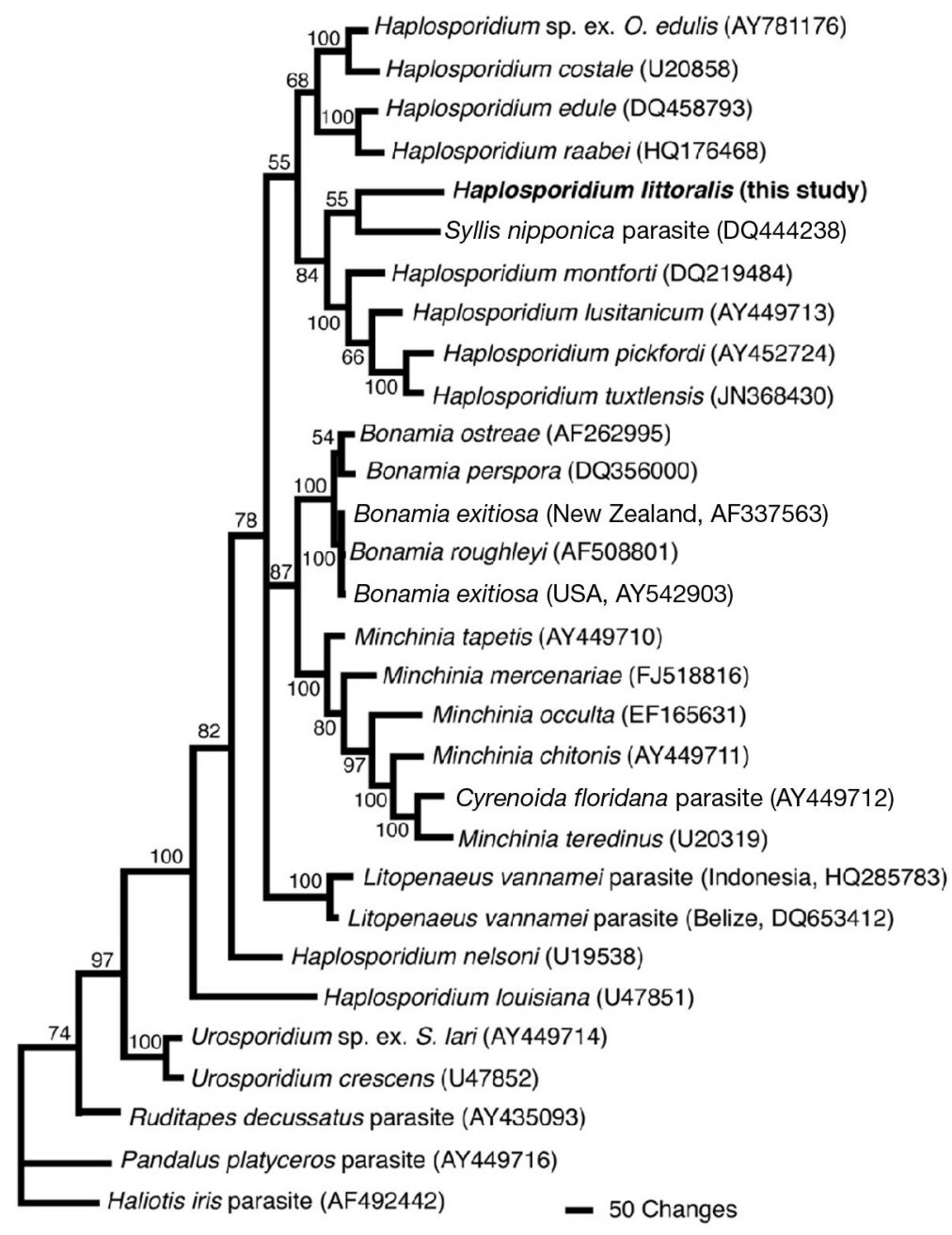

Fig. 2. Results of parsimony bootstrap analysis: $50 \%$ majority rule consensus tree, with numbers at nodes representing percentages of 1000 bootstrap replicates. Tree length $=4170$, retention index $=0.56$, consistency index $=0.51$

\section{Haplosporidium littoralis sp. nov.}

Diagnosis: Uninucleate and multinucleate plasmodial life stages within haemocytes, connective tissue cells, fixed phagocytes and myocytes of Carcinus maenas (previously observed by Stentiford et al. 2004). Spore stages not observed to date but cannot be ruled out. Phylogenetic analysis places the parasite within the genus Haplosporidium; hence spore architecture similar to other members of this genus may be expected.

Type host: European shore crab Carcinus maenas

Type location: Newton's Cove, Weymouth, UK $\left(50^{\circ} 34^{\prime} \mathrm{N}, 2^{\circ} 22^{\prime} \mathrm{W}\right)$

Hepantotype material: Reference materials are deposited at the US National Parasite Collection, US
Department of Agriculture, Beltsville, MD. Accession numbers USNPC 101497 and USNPC 1201498.

Ribosomal DNA sequence: Deposited to GenBank under accession number JX185413.

Etymology: The specific epithet refers to shore line (littoral) habitat of the type host.

\section{DISCUSSION}

Despite their significant economic importance and their dramatic effect on the health status of aquatic invertebrates, the haplosporidians remain a significantly understudied group, with relatively sparse representation within public genomic databases. Attempts to utilise solely morphological traits of known pathogens within the group have proved somewhat inconclusive, with strong suggestion of paraphyly in at least some genera (Hine et al. 2009), whilst global studies using molecular phylogenetic approaches have been somewhat hampered by a lack of available source material from infected animals and the absence of sequence data from morphologically-defined isolates. As if this were not sufficient to lead to taxonomic confusion, the structure of higher-level phylogenies have also been the subject of significant debate, with major changes a result of novel discoveries and emerging approaches to molecular taxonomy (Cavalier-Smith 2002, CavalierSmith \& Chao 2003a,b).

Nonetheless, despite these taxonomic issues, the haplosporidians and their sister order within the Ascetosporea, the paramyxids, remain important pathogen groups since they can significantly impact upon the health of invertebrates and can drive mortality within infected populations (e.g. Burreson et al. 2000). This impact has led to representative members (e.g. Bonamia ostreae and B. exitiosa spp. within the Haplosporida and Marteilia refringens within the Paramyxida) being listed in the international legislation of the European Union (Directive 2006/88/EC) and of the World Organisation for Animal Health (OIE 2012). This listing provides an important political tool by which national governments can control 

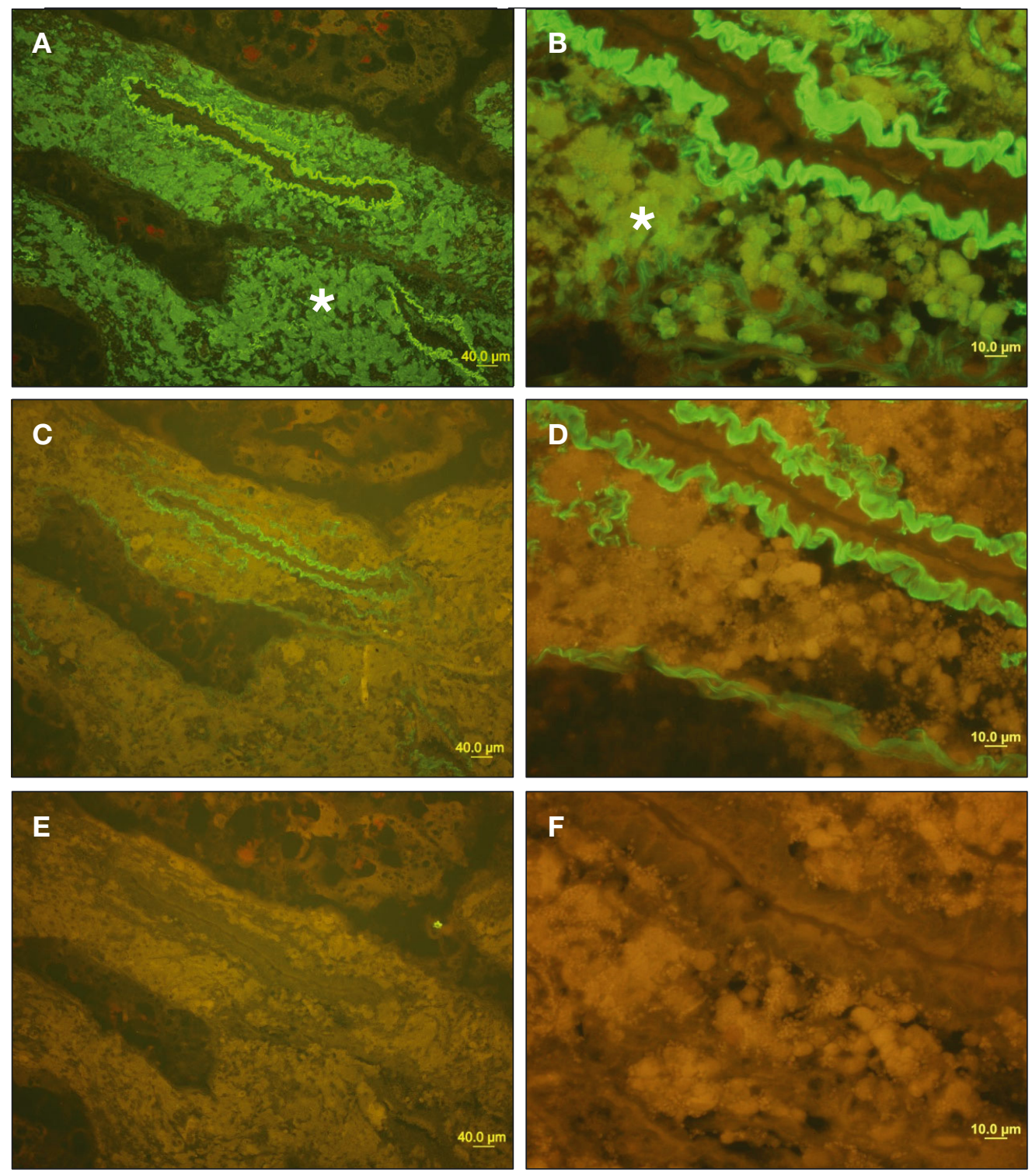

Fig. 3. Carcinus maenas. Fluorescent in situ hybridisation of hepatopancreas from crabs infected with Haplosporidium littoralis. Positive staining of $H$. littoralis with specific probe (asterisks) at (A) low and (B) high power. No staining of $H$. littoralis with Perkinsus marinus probe at (C) low and (D) high power or in no-probe negative control at (E) low and (F) high power

the import of aquatic animals and products derived from them, based upon the important pathogens that they may be carrying. In this context, improved taxonomy of the group is a key driver in protecting national biosecurity whilst not unduly restricting free trade.

The current study has provided such taxonomic clarity for an unclassified 'haplosporidian-like' pathogen previously described by our laboratory (Stentiford et al. 2004). The parasite, hereby named Haplosporidium littoralis, causes severe alterations to the connective tissues and haemolymph of infec- ted crabs. The prevalence of infection observed here $(7.6 \%)$ was remarkably similar to our previous observation ( $7 \%$; Stentiford et al. 2004), and since we consider that infection leading to disease would be terminal, we continue to assume that the parasite is lethal to infected individuals. The parasite therefore is considered to be a mortality driver in populations of Carcinus maenas.

Based upon parsimony analysis against the SSU rDNA sequences of other haplosporidian parasites, we report that the crab parasite is sister to the gastropod mollusc parasites Haplosporidium montforti, 

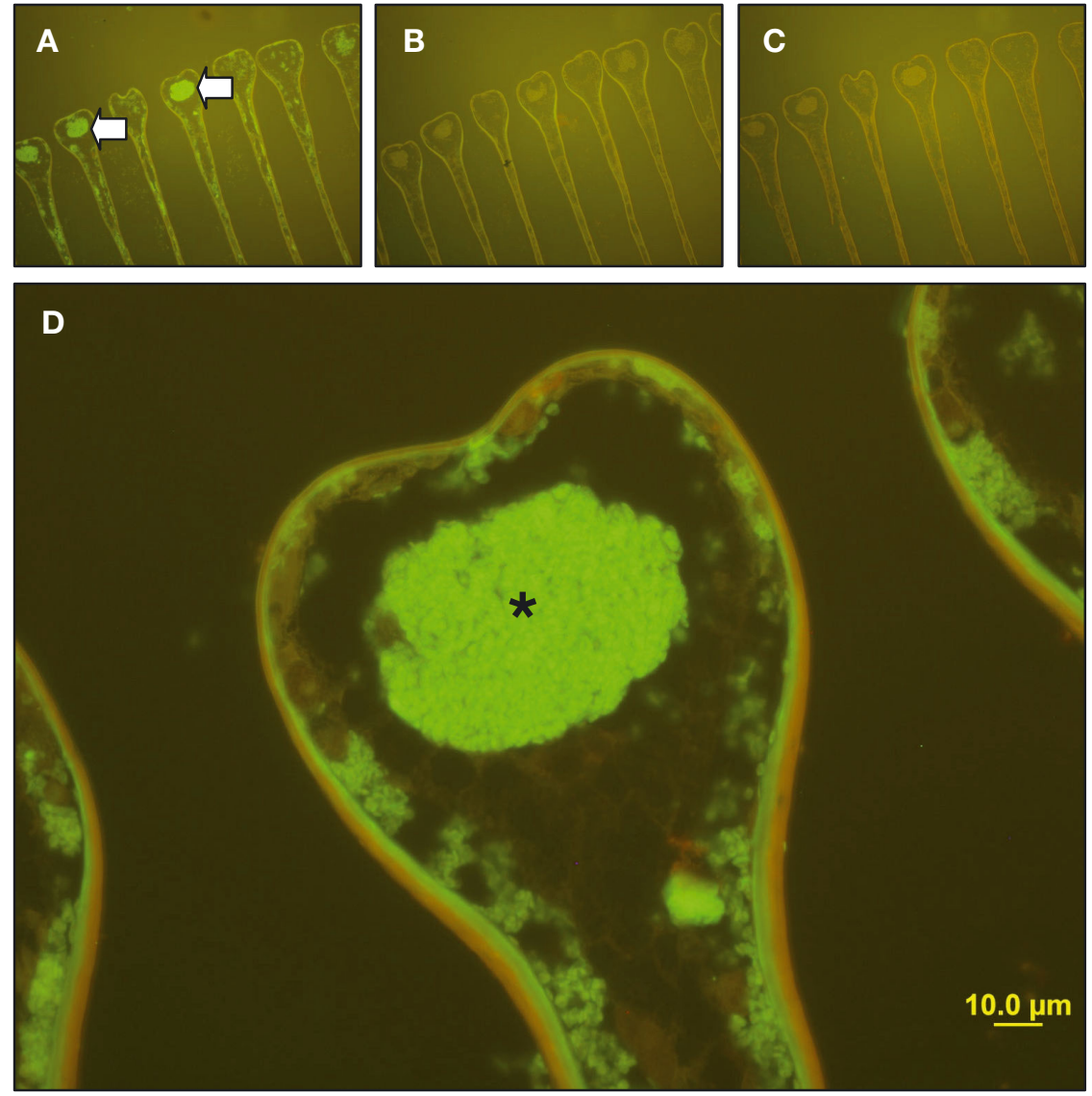

Fig. 4. Carcinus maenas. Fluorescent in situ hybridisation of gills from crabs infected with Haplosporidium littoralis. (A) Positive staining of $H$. littoralis with specific probe (arrows) at low power. No staining of $H$. littoralis with (B) Perkinsus marinus probe or (C) no-probe negative control. (D) Positive staining of $H$. littoralis with specific probe at high power. Parasite life stages are present within the haemal spaces (asterisk)

H. lusitanicum and $H$. pickfordi, and to a parasite from the polychaete Syllis nipponica. The relationship of the crab parasite to existing members of the genus Haplosporidium is somewhat surprising given that other known haplosporidian parasites from marine crustaceans, including those from the Pacific white shrimp Litopenaeus vannamei (Nunan et al. 2007, Utari et al. 2012) and particularly another from the spot prawn Pandalus platyceros (Reece et al. 2000), were shown to be phylogenetically dissimilar to $H$. littoralis from European crabs. Despite the rather limited literature on this subject, the relatively wide variation in SSU rDNA gene sequence among these 3 parasites is suggestive of an underlying diversity in the as-yet undiscovered haplosporidian fauna infecting crustacean hosts. Furthermore, it appears to suggest a closer relationship between certain haplosporidians infecting ecologically-associated crustacean and molluscan hosts than to geo- graphically and ecologically distinct hosts of the same taxa.

Haplosporidium montforti (Azevedo et al. 2006), H. lusitanicum (Azevedo 1984) and H. pickfordi Barrow, 1961 are parasites of the European abalone Haliotis tuberculata, the blue-rayed limpet Helcion pellucidus and the freshwater Gatineau tadpole snail Physella parkeri, respectively. The hosts $H$. tuberculata and $H$. pellucidis are marine shoreline gastropods found along the coastlines of Europe. The former has a marginal niche overlap with populations of Carcinus maenas (e.g. in the Channel Islands of the southern English Channel) but has not been recorded along the coastline of the northern English Channel (site of the current study). In contrast, $H$. pellucidis is a common inhabitant of kelp (e.g. Laminaria hyperborea) in the lower eulittoral zone of European coastlines (Marine Life Information Network: http://www.marlin. ac.uk). The presence of a phylogenetically similar Haplosporidium species in closely associated organisms from this shoreline habitat is intriguing and suggests the possibility that haplosporidians within this genus can passage between molluscan and crustacean hosts. Furthermore, the potential for multi-trophic transfer of haplosporidians could also account for the apparent absence of particular life stages (such as the spore) and organelles (haplosporosomes) in some of the 'asporous' haplosporidians of crustacean hosts as defined by Hine et al. (2009).

Numerous authors have reported ultrastructural and phylogenetic data that show the genus Haplosporidium to be paraphyletic (Burreson \& Ford 2004, Burreson \& Reece 2006, Hine et al. 2009). Evidence for this is focussed on existing members of the genus often bearing little morphological resemblance to the type species of the genus, $H$. scolopli Caullery and Mesnil, 1899 in polychaete worms, and to the basal phylogenetic position of $H$. nelsoni and $H$. louisiana relative to not only Haplosporidium spp. but to Bonamia spp. and Minchinia spp. as well (Fig. 2). In 
reference to this, Hine et al. (2009) proposed that with the exception of $H$. parisi (which is similar in appearance and also infects polychaetes), none of the other ultrastructurally-described Haplosporidium spp. belong in that genus. They also state that with the exception of certain groupings (e.g. the gastropod Haplosporidium spp.), none are congeneric. The discussions are summarised by stating the requirement for major taxonomic revision of the Haplosporida based on molecular and ultrastructural studies, in particular relating to the diverse genus Haplosporidium. The current study has provided a somewhat different perspective on this issue by using molecular phylogenetic and ecological association data to propose that representatives of the genus can infect a wide taxonomic range of hosts, and that morphological traits of parasite isolates may not be a reliable indicator for relatedness - a phenomenon increasingly recognised within the wider field of marine parasitology (Stentiford et al. 2013). It also provides tentative evidence that certain members of the Haplosporida may possess the potential to passage between hosts of different taxonomic hierarchy and further, that a paraphyletic status of the genus Haplosporidium may instead reflect life cycle complexity within this taxon. Such observations are consistent with those of Bearham et al. (2009), who showed that Minchinia occulta (another haplosporidian) can infect molluscan hosts within 2 different families. Nonetheless, the addition of phylogenetic data on haplosporidian pathogens to public genomic databases will continue to enhance resolution of this important but enigmatic pathogen group.

Acknowledgements. The authors acknowledge support from the UK Department for Environment, Food and Rural Affairs (Defra) under grant \#FC1205 (to G.D.S.) and from the European Commission under grant \#C5409 (to G.D.S.). This is VIMS contribution \#3291.

\section{LITERATURE CITED}

- Altschul SF, Madden TL, Schäffer AA, Zhang J, Zhang Z, Miller W, Lipman DJ (1997) Gapped BLAST and PSIBLAST: a new generation of protein database search programs. Nucleic Acids Res 25:3389-3402

> Azevedo C (1984) Ultrastructure of the spore of Haplosporidium lusitanicum sp. n. (Haplosporida, Haplosporidiidae), parasite of a marine mollusc. J Parasitol 70: 358-371

> Azevedo C, Balseiro P, Casal G, Gestal C and others (2006) Ultrastructural and molecular characterization of Haplosporidium montforti, n. sp., parasite of the European abalone Haliotis tuberculata. J Invertebr Pathol 92:23-32

Bearham D, Spiers ZB, Raidal SR, Jones JB, Nicholls PK
(2009) Detection of Minchinia occulta in samples of pearl oysters Pinctada maxima infected by Haplosporidium hinei. Aust Vet J 87:430-437

> Bower SM, Meyer GR (2002) Morphology and ultrastructure of a protistan pathogen in the haemolymph of shrimp (Pandalus spp.) in the northern Pacific Ocean. Can J Zool 80:1055-1068

Bower SM, Carnegie RB, Goh B, Jones SRM, Lowe GJ, Mak MWS (2004) Preferential PCR amplification of parasitic protistan small subunit rDNA from metazoan tissues. J Eukaryot Microbiol 51:325-332

Burreson EM, Ford SE (2004) A review of recent information on the Haplosporidia, with special reference to Haplosporidium nelsoni (MSX disease). Aquat Living Resour 17:499-517

Burreson EM, Reece KS (2006) Spore ornamentation of Haplosporidium nelsoni and Haplosporidium costale (Haplosporidia), and incongruence of molecular phylogeny and spore ornamentation in the Haplosporidia. J Parasitol 92:1295-1301

Burreson EM, Stokes NA, Friedman CS (2000) Increased virulence in an introduced pathogen: Haplosporidium nelsoni in the eastern oyster Crassostrea virginica. J Aquat Anim Health 12:1-8

Carnegie RB, Barber BJ, Culloty SC, Figueras AJ, Distel DL (2000) Development of a PCR assay for detection of the oyster pathogen Bonamia ostreae and support for its inclusion in the Haplosporidia. Dis Aquat Org 42: 199-206

Carnegie RB, Meyer GR, Blackbourn J, Cochennec-Laureau N, Berthe FCJ, Bower SM (2003) Molecular detection of the oyster parasite Mikrocytos mackini, and a preliminary phylogenetic analysis. Dis Aquat Org 54: 219-227

> Carnegie RB, Burreson EM, Hine PM, Stokes NA, Audemard C, Bishop MJ, Peterson CH (2006) Bonamia perspora n. sp. (Haplosporidia), a parasite of the oyster Ostreola equestris, is the first Bonamia species known to produce spores. J Eukaryot Microbiol 53:232-245

Cavalier-Smith T (1998) A revised six-kingdom system of life. Biol Rev Camb Philos Soc 73:203-266

> Cavalier-Smith T (2002) The phagotrophic origin of eukaryotes and phylogenetic classification of Protozoa. Int $\mathrm{J}$ Syst Evol Microbiol 52:297-354

> Cavalier-Smith T, Chao EEY (2003a) Phylogeny and classification of phylum Cercozoa (Protozoa). Protist 154: 341-358

> Cavalier-Smith T, Chao EEY (2003b) Phylogeny of Choanozoa, Apusozoa, and other protozoa and early eukaryote megaevolution. J Mol Evol 56:540-563

> Dyková I, Lom J, Fajer E (1988) A new haplosporean infecting the hepatopancreas in the penaeid shrimp, Litopenaeus vannamei. J Fish Dis 11:15-22

Elston RA, CF Dungan, TR Meyers, KS Reece (2004) Perkinsus sp. infection risk for Manila clams, Venerupis philippinarum (A. Adams and Reeve, 1850) on the Pacific coast of North and Central America. J Shellfish Res 23: 1101-1105

Hine PM, Carnegie RB, Burreson EM, Engelsma MY (2009) Inter-relationships of haplosporidians deduced from ultrastructural studies. Dis Aquat Org 83:247-256

Larsson JIR (1987) On Haplosporidium gammari, a parasite of the amphipod Rivulogammarus pulex, and its relationships with the phylum Ascetospora. J Invertebr Pathol 49:159-169 
Marchand J, Sprague V (1979) Ultrastructure de Minchinia cadomensis sp. n. (Haplosporida) parasite du décapode Rhithropanopeus harrisii tridentatus Maitland dans le canal de Caen à la mer (Calvados, France). J Protozool 26:179-185

Medlin L, Elwood HJ, Stickel S, Sogin ML (1988) The characterization of enzymatically amplified eukaryotic 16Slike rRNA-coding proteins. Gene 71:491-499

Messick GA (2009) Haplosporidian parasite in Diporeia spp. amphipods from the Great Lakes region, USA. Dis Aquat Org 83:153-157

Meyers TR, Lightner DV, Redman RM (1994) A dinoflagellate-like parasite in Alaskan spot shrimp Pandalus platyceros and pink shrimp P. borealis. Dis Aquat Org 18: 71-76

Newman MW, Johnson CA, Pauley GB (1976) A Minchinia like haplosporidan parasitizing blue crabs, Callinectes sapidus. J Invertebr Pathol 27:311-315

Nunan LM, Lightner DV, Pantoja CR, Stokes NA, Reece KS (2007) Characterization of a rediscovered haplosporidian parasite from cultured Penaeus vannamai. Dis Aquat Org 74:67-75

OIE (World Organisation for Animal Health) (2012) Manual of diagnostic tests for aquatic animals, 7th edn, 2012. OIE, Paris

Perkins FO (2000) Phylum Haplosporidia Caullery \& Mesnil, 1899. In: Lee JJ, Leedale GF, Bradbury P (eds) The illustrated guide to the Protozoa. Society of Protozoologists, Lawrence, KS, p 1329-1341

Perkins FO, van Banning P (1981) Surface ultrastructure of spores in three genera of Balanosporida, particularly Minchinia armoricana van Banning, 1977. The taxonomic significance of spore wall ornamentation in the Balanosporida. J Parasitol 67:866-874

Reece KS, Burreson EM, Bower SM, Dungan CF (2000) Molecular analyses of a parasite in prawns (Pandalus

Editorial responsibility: Sven Klimpel,

Frankfurt, Germany platyceros) from British Columbia, Canada. J Shellfish Res 19:647 (Abstract)

- Reece KS, Siddall ME, Stokes NA, Burreson EM (2004) Molecular phylogeny of the Haplosporidia based on two independent gene sequences. J Parasitol 90: $1111-1122$

Renault T, Stokes NA, Chollet B, Cochennec N, Berthe F, Gérard A, Burreson EM (2000) Haplosporidiosis in the Pacific oyster Crassostrea gigas from the French Atlantic coast. Dis Aquat Org 42:207-214

Reynolds ES (1963) The use of lead citrate at high pH as an electron-opaque stain in electron microscopy. J Cell Biol 17:208-212

Rosenfield A, Buchanan L, Chapman GB (1969) Comparison of the fine structure of spores of three species of Minchinia (Haplosporida, Haplosporidiidae). J Parasitol 55: 921-941

Sprague V (1963) Revision of the genus Haplosporidium and restoration of the genus Minchinia (Haplosoridia, Haplosporidiidae). J Protozool 10, 263-266

Stentiford GD, Feist SW, Bateman KS, Hine PM (2004) Haemolymph parasite of the shore crab Carcinus maenas: pathology, ultrastructure and observations on crustacean haplosporidians. Dis Aquat Org 59:57-68

Stentiford GD, Bateman KB, Feist SW, Chambers E, Stone DM (2013) Plastic parasites: extreme dimorphism creates a taxonomic conundrum in the phylum Microsporidia. Int J Parasitol 43:339-352

Swofford DL (2002) PAUP* $^{*}$ : phylogenetic analysis using parsimony (*and other methods), Version 10. Sinauer Associates, Sunderland, MA

Utari HB, Senapin S, Jaengsanong C, Flegel TW, Kruatrachue M (2012) A haplosporidian parasite associated with high mortality and slow growth in Penaeus (Litopenaeus) vannamei cultured in Indonesia. J Invertebr Pathol 92: 23-32

Submitted: March 1, 2013; Accepted: May 16, 2013

Proofs received from author(s): July 29, 2013 